\title{
Impact of prediabetes on cardiovascular disease risk in patients with acute myocardial infarctions
}

\author{
Akut miyokard enfarktüslü hastalarda prediyabetin kardiyovasküler hastalık riskine etkisi
}

\author{
Özge Çakmak Karaaslan ${ }^{1}$, Murat Oğuz Özilhan ${ }^{1}$, Cem Çöteli ${ }^{1}$, Orhan Maden ${ }^{1}$
}

\begin{abstract}
Aim: Prediabetes is known to be associated with increased cardiovascular diseases (CVD) risk and mortality. It has been reported that more than $70 \%$ of pre-diabetic patients develop Diabetes Mellitus (DM). In patients with acute myocardial infarction (AMI), diabetes increases a 2 to 4 fold risk of adverse cardiovascular events compared to non-diabetic patients. This morbidity-mortality relationship begins in the progression phase from normal glucose tolerance to diabetes. We evaluated the relationship between the presence of pre-diabetes by using hemoglobin A1c (HbA1c) values and CVD risk in patients presenting with newly diagnosed AMI.

Methods: This study was a retrospective, single-centre and we examined consecutive patients who underwen coronary angiography with a diagnosis of AMI at our hospital between March 2019 and September 2020. A total of 332 patients with AMI were enrolled; patients were divided into two groups according to their HbA1c levels: non-diabetic group $(\mathrm{HbA} 1 \mathrm{c}<5.7 \%)$ and pre-diabetic group $(5.7 \% \leq \mathrm{HbA} 1 \mathrm{c}<6.05 \%)$. The primary composite endpoints were cardiovascular death, myocardial infarction or stroke.

Results: Of the 332 patients, $204(61 \%)$ patients had non-diabetic groups, and $128(39 \%)$ patients were between the pre-diabetic groups. During the follow-up period, the primary composite endpoints amounted to $7.4 \%$ and $15.6 \%$ in the non-diabetes and prediabetes group $(\mathrm{p}=0.026)$. The incidences of cardiovascular death and myocardial infarction were significantly higher in the prediabetic group than the nondiabetic group $(p=0.021$, $\mathrm{p}=0.004$; respectively). Independent predictors for the primary composite endpoints following the multivariate analysis included SYNTAX score (odds ratio [OR]: 0.912; \%95 confidence interval [CI]: $0.832-0.999$, p 0.047), left ventricular ejection fraction (OR: 0.812; \%95 CI: 0.753- 0.876, p< 0.001), systolic blood pressure (OR: 0.955; \%95 CI: 0.927- 0.985, p: 0.003) and valuable categorical HbA1c $(5.7 \% \leq \mathrm{HbA} 1 \mathrm{c}<6.5 \%)(\mathrm{OR}: 2.787$; \%95 CI: 1.091- 7.120, p: 0.032)

Conclusion: Prediabetes group has been shown to have a higher incidence of the primary composite endpoints than non-diabetes. SYNTAX score, left ventricular ejection fraction, systolic blood pressure, and HbA1c (categorical variable) were found as independent predictors for the primary composite endpoint. Preventive measures in the stage of pre-diabetes might help the prevention of developing CVD.

Keywords: Cardiovascular diseases, myocardial infarction, prediabetic state.
\end{abstract}

\section{Öz}

Amaç: Prediyabetin artmış kardiyovasküler hastalıklar $(\mathrm{KVH})$ riski ve mortalite ile ilişkili olduğu bilinmektedir. Prediyabetik hastaların \%70'inden fazlasında Diabetes Mellitus (DM) geliștiği bildirilmiștir. Akut miyokard enfarktüsü (AME) olan hastalarda diyabet, diyabetik olmayan hastalara kıyasla istenmeyen kardiyovasküler olay riskini 2-4 kat artırır. Bu morbidite-mortalite ilişkisi normal glukoz toleransından diyabete ilerleme aşamasında başlar. Yeni tanı almış AME ile başvuran hastalarda, hemoglobin A1c (HbAlc) değerleri kullanılarak prediyabet varlığı ile KVH riski arasındaki ilişkiyi değerlendirdik.

Yöntemler: Bu çalıșma retrospektif, tek merkezli olup, Mart 2019-Eylül 2020 tarihleri arasında ardısıık olarak, hastanemizde AME tanısı ile koroner anjiyografi yapılan hastalar incelendi. Toplam 332 AME hastas kaydedildi; hastalar HbA1c düzeylerine göre 2 gruba ayrıldı: diyabetik olmayan grup (HbA1c <\%5,7, $\mathrm{n}=204)$ ve prediyabetik grup $(\% 5,7 \leq \mathrm{HbAlc}<\% 6,5, \mathrm{n}=128)$. Birincil bileşik son noktalar, kardiyovasküler ölüm, miyokardiyal enfarktüs ve inme olarak belirlendi.

Bulgular: 332 hastanın 204'ü (\%61) diyabetik olmayan gruba, 128 (\%39) hasta prediyabetik grup arasındaydı. Takip süresi boyunca, birincil birleşik sonlanım noktaları diyabet olmayan ve prediyabet grubunda $\% 7,4$ ve $\% 15,6$ olarak bulundu $(\mathrm{p}=0,026)$. Prediyabetik grupta kardiyovasküler ölüm ve miyokard infarktüsü insidans1, diyabetik olmayan gruba göre anlamlı olarak daha yüksekti (sırasıyla $p=0,021, p=0,004$ ). Çok değişkenli analizi takiben birincil birleşik sonlanım noktaları için bağımsız öngörücüler arasında SYNTAX skoru (OR: 0,912; \%95 GA: 0,832- 0,999, p: 0,047) , sol ventriküler ejeksiyon fraksiyonu (OR: 0,812; \%95 GA: 0,7530,876, p < 0,001), sistolik kan basıncı (OR: 0,955; \%95 GA: 0,927- 0,985, p: 0,003) ve kategorik değerli HbA1c $(\% 5,7 \leq \mathrm{HbAlc}<\% 6,5)(\mathrm{OR}: 2,787 ; \% 95$ GA: 1,091- 7,120, p: 0,032) yer ald1.

Sonuç: Prediyabet grubunun diyabet olmayanlara kıyasla birincil bileşik sonlanım noktalarının daha yüksek insidansına sahip olduğu gösterilmiştir. Bileşik sonlanım noktası için bağımsız öngörücü olarak SYNTAX skoru, sol ventriküler ejeksiyon fraksiyonu, sistolik kan basıncı ve HbAlc (kategorik değişken) bulundu. Prediyabet aşamasında önleyici tedbirler, KVH gelişiminin önlenmesine yardımcı olabilir.

Anahtar kelimeler: Kardiyovasküler hastalıklar, miyokard enfarktüsü, prediyabetik durum.
${ }^{1}$ University of Health Sciences, Ankara City Hospital, Department of Cardiology, Ankara, Turkey.

ID

ÖÇ: 0000-0003-0173-4017

MOÖ: 0000-0003-4801-966X

CÇ: 0000-0001-5520-7103

OM: 0000-0003-3170-1179

Ethics Committee Approval: This study was approved by the Health Sciences University Ankara City Hospital Ethics Committee with an approval number of 1486-03.02.2021.

Etik Kurul Onayı: Bu çalışma Sağlık Bilimleri Üniversitesi Ankara Şehir Hastanesi Etik Kurulu tarafindan 1486-03.02.2021 onay numarasi ile onaylanmıştır

Conflict of Interest: No conflict of interest was declared by the authors.

Çıkar Çatışması: Yazarlar çıkar çatıșması bildirmemiștir.

Financial Disclosure: The authors declared that this study has received no financial support.

Finansal Destek: Yazarlar bu çalıșma için finansal destek almadıklarını beyan etmișlerdir.

Gelis Tarihi / Received: 18.02 .2021

Kabul Tarihi / Accepted: 26.05.2021

Yayın Tarihi / Published: 02.08.2021

Sorumlu yazar / Corresponding author: Özge Çakmak Karaaslan

Adres/Address: Ankara City Hospital, Cardiology

Clinic, Ankara, Turkey.

e-mail: ozgecakmak2323@gmail.com

Tel/Phone: +90 5377395670

Fax: +903123061000

Copyright $\odot$ ACEM 


\section{Introduction}

Diabetes mellitus (DM) is a significant risk factor for cardiovascular diseases (CVD) [1]. In patients with acute myocardial infarction (AMI), diabetes increases a 2- to 4-fold risk of adverse cardiovascular events compared to nondiabetic patients [2]. DM is one of the most critical risk factors in the development of coronary artery disease (CAD), and it alone is responsible for $9.9 \%$ of the risk of having the first AMI [3]. However, previous studies have shown that this morbiditymortality relationship begins in the progression phase from normal glucose tolerance to diabetes [4] [5].

Prediabetes is defined as the period before developing symptomatic diabetes when fasting blood glucose concentration is below the limit values for the diagnosis of DM [6]. Prediabetes is known to be associated with increased cardiovascular risk and mortality [7]. It has been acknowledged that prediabetes status is diagnosed based on fasting blood glucose measures, 2-hours plasma glucose after an OGTT, or hemoglobin A1c (HbA1c) [8]. The OGTT in patients with AMI may lead to false evaluation due to acute stress hormones during the peri-infarction period. It isn't easy to perform in this period, so HbA1c is commonly preferred over the OGTT in clinical practice [9]. In addition, it has been shown that prediabetes defined by HbA1c was associated with a poor prognosis for CVD than prediabetes defined by fasting blood glucose or 2-hours plasma glucose [10].

It has been observed that there are significant inconsistencies between reports due to the use of different cutting points and reference groups [11]. It has been known that direct comparisons using HbA1c measurement with CVD development are rare in the same population [12].

Therefore, we evaluated the relationship between prediabetes status defined by HbA1c and CVD development in patients presenting with newly diagnosed AMI.

\section{Material and methods}

This study was a retrospective, single-centre and we examined consecutive patients who underwent coronary angiography with a diagnosis of AMI (ST-elevation and non-STelevation myocardial infarction) at our hospital between March 2019 and September 2020. We have retrospectively evaluated records of 1016 patients diagnosed with acute myocardial infarction between March 2019 and September 2020. This study was prepared by the Declaration of Helsinki and good clinical use guidelines. The local ethics committee approved this study (Date: 03.02.2021, Number: E1-21-1486).

A total of 608 patients who a history of known coronary artery disease, diabetes or newly diagnosed diabetes $(\mathrm{HbA} 1 \mathrm{c} \geq$ $6.5 \%$ ) during hospital admission, and 76 patients with missing medical data were excluded from the study. The remaining 332 patients comprised the study cohort.

Patients were divided into 2 groups according to their HbA1c levels: nondiabetic group (HbA1c <5.7\%, n=204) and prediabetic group $(5.7 \% \leq \mathrm{HbAlc}<6.5 \%, \mathrm{n}=128)$ according to 2020 American Diabetes Association (ADA) definition [6].

The primary composite endpoints were cardiovascular death, myocardial infarction or stroke. Cardiovascular death was included sudden cardiac death, death due to acute myocardial infarction, death due to heart failure, death due to a cerebrovascular event and deaths for which there was no clearly documented non-cardiovascular cause (presumed cardiovascular death). Stroke was defined as an acute event of neurologic dysfunction attributed to a central nervous system vascular cause documented by imaging (e.g., computed tomography or magnetic resonance imaging). AMI is diagnosed based on the Universal Myocardial Infarction definition published by Thygesen et al. [13] in 2018.

The reason for death was evaluated by obtained death information from National Survival Registry and the hospital database's records. Patients were followed up for a median of 10 months ( \pm 6 months). It was recorded the $1 \mathrm{st}, 3 \mathrm{rd}$ and 6 th months follow-up visits after discharge from the hospital records. The primary composite endpoints were adjudicated by a researcher that was blinded to admission HbA1c level.

As a previous diagnosis of diabetes, DM was defined as usage of oral hypoglycaemic agents or insulin, or HbA1C levels $\geq 6.5 \%$ in the blood sample at admission hospital [14]. Prediabetes was defined as an admission $\mathrm{HbA1c}$ value of $5.7-6.4 \%$ in patients without previously diagnosed DM [15]. Dyslipidemia (total cholesterol level of $\geq 200 \mathrm{mg} / \mathrm{dL}$ in the fasting state or lowdensity lipoprotein (LDL) cholesterol $\geq 140 \mathrm{mg} / \mathrm{dL}$ or use of cholesterol-lowering agents) and hypertension (HT) (use of antihypertensive medications or a previous diagnosis of HT) evaluated as risk factors for CAD.

The diagnosis of AMI was established on the existence of an increase or fall of cardiac biochemical markers (creatinine kinase-MB and troponin I or T) except normal range and with at least one of the following: clinical symptoms of ischemia, novel or assumed new important ST-segment-T wave changes or novel left bundle branch block, the establishment of pathological Q waves in the electrocardiography, and imaging evidence of new regional wall motion abnormality [13].

Samples for creatinine, alanine aminotransferase (ALT), estimated glomerular filtration rate (eGFR), hemogram, HbA1c, and $\mathrm{C}$-reactive protein (CRP), troponin I were taken at admission and fasting blood glucose, triglycerides (TG), total cholesterol (TC), high- density lipoprotein (HDL) cholesterol and LDL cholesterol were measured on the at admission. Data respecting baseline characteristic and clinical features, risk factors and laboratory parameters of all patients were obtained from followup visits, patients' records and the electronic hospital database.

Left ventricular ejection fraction (LVEF) was measured using the modified Simpson method.

\section{Statistical analysis}

Data were analysed using the IBM SPSS 22.0 Statistical Package Program for Windows (IBM SPSS, Inc., IL, USA). The Shapiro-Wilk test was utilized to test the normality of distribution. Continuous variables were expressed as mean \pm standard deviation if normally distributed or median median (min-maks) if not distributed normally. Categorical variables were expressed as the number of patients and percentages. Student t-test was used to compare mean values and Chi-square or Fisher's Exact test was used to compare categorical variables as appropriate. The Mann-Whitney $U$ test was utilized to compare continuous variables that were not distributed normally.

A univariate logistic regression analysis was used to evaluate each variable's association with the primary composite endpoint occurrence. Univariate logistic regression analysis was performed for the following parameters: SYNergy between PCI with TAXUS and Cardiac Surgery (SYNTAX) score, Thrombolysis in Myocardial Infarction (TIMI) thrombus grade, LVEF, age, ST-Elevation myocardial infarction (STEMI), heart rate, systolic blood pressure (SBP), eGFR, hemoglobin and $\mathrm{HbA1c}$ as a categorical parameter. The enter methods were used for determining variables with the association of the primary composite endpoint in the multivariate logistic regression analysis. Parameters smaller than p-value 0.05 are put into 
multivariate logistic regression analysis was made. A p-value $<0.05$ was considered significant.

\section{Results}

Baseline clinical, demographic and laboratory characteristics are showed in Table 1. Of the 332 patients, 204 (61\%) patients had HbA1c <5.7\% (Nondiabetic Group) and 128 (39\%) patients were between HbA1c 5.7-6.4\% (Prediabetic Group). The prediabetic group has an older, higher heart rate and higher systolic blood pressure than the non-diabetic group $(\mathrm{p}=$ $0.014, \mathrm{p}<0.001, \mathrm{p}<0.001$; respectively). The male gender ratio was similar between the two groups. There were no differences in terms of hypertension, dyslipidemia and known heart failure between groups. LVEF was similar in both groups. As expected, glucose values were higher in the prediabetic group $(\mathrm{p}<0.001)$. There was no statistically significant difference regarding, creatinine, ALT, TC, TG, LDL, HDL, eGFR, white blood cell count, hemoglobin, CRP, troponin levels, between non-diabetes and pre-diabetes groups. There was no difference in the use of the prescribed medications after discharge among the groups (Table 1). The rate of NSTEMI and STEMI were similar between groups. In prediabetes group had a higher prevalence of left main coronary artery disease $(\mathrm{p}<0.001)$. The prevalence of left anterior descending coronary artery, left circumflex coronary artery, and right coronary artery diseases were similar. There were no differences in terms of angiographic TIMI thrombus grade and SYNTAX scores between the groups. The Selection of revascularization was similar between groups (Table 2).

Table 1.

Table 1. Baseline demographical and clinical characteristics of the study population.

\begin{tabular}{|c|c|c|c|}
\hline & $\begin{array}{c}\text { Non-diabetic patients } \\
(\mathrm{n}=204)\end{array}$ & $\begin{array}{l}\text { Prediabetic patients } \\
(\mathrm{n}=128)\end{array}$ & $\mathrm{p}$ \\
\hline Age (year) ${ }^{\dagger}$ & $55 \pm 19$ & $60.50 \pm 17.75$ & 0.014 \\
\hline Male & $164(80 \%)$ & $108(84 \%)$ & 0.359 \\
\hline Heart rate (beat/min) & $69 \pm 13$ & $79.50 \pm 21.75$ & $<0.001$ \\
\hline $\mathrm{SBP}_{\mathrm{mmHg}}{ }^{\dagger}$ & $130 \pm 10$ & $120 \pm 20$ & $<0.001$ \\
\hline Hypertension & $52(25.5)$ & $36(28.1)$ & 0.611 \\
\hline Dyslipidemia & $16(7.8)$ & $12(9.4)$ & 0.686 \\
\hline Known heart failure & $40(19.6)$ & $16(12.5)$ & 0.092 \\
\hline $\operatorname{LVEF}^{\dagger}(\%)^{\dagger}$ & $50 \pm 10$ & $50 \pm 10.25$ & 0.636 \\
\hline NSTEMI ${ }^{\ddagger}$ & $92(45)$ & $64(50)$ & 0.429 \\
\hline STEMI ${ }^{\ddagger}$ & $112(55)$ & $64(50)$ & 0.384 \\
\hline \multicolumn{4}{|l|}{ Admission } \\
\hline Glucose $(\mathrm{mg} / \mathrm{dl})^{\dagger}$ & $96.00 \pm 20$ & $106.50 \pm 24$ & $<0.001$ \\
\hline Creatinine $(\mathrm{mg} / \mathrm{dl})$ & $0.80(0.4-1.1)$ & $0.80(0.4-1.5)$ & 0.274 \\
\hline $\operatorname{ALT}(\mathrm{U} / \mathrm{L})^{\dagger}$ & $24.00 \pm 18.00$ & $25.00 \pm 16.00$ & 0.888 \\
\hline $\mathrm{TC}(\mathrm{mg} / \mathrm{dl})^{\dagger}$ & $180.00 \pm 51.00$ & $183.50 \pm 53.25$ & 0.398 \\
\hline Triglycerides $(\mathrm{mg} / \mathrm{dl})^{\dagger}$ & $106.00 \pm 77.00$ & $113.00 \pm 81.25$ & 0.085 \\
\hline LDL-C $(\mathrm{mg} / \mathrm{dl})^{\dagger}$ & $115.00 \pm 52.00$ & $124.00 \pm 58.50$ & 0.247 \\
\hline $\operatorname{HDL}-\mathrm{C}(\mathrm{mg} / \mathrm{dl})^{\dagger}$ & $35.00 \pm 12.00$ & $41.00 \pm 12.75$ & 0.124 \\
\hline $\mathrm{eGFR}\left(\mathrm{ml} / \mathrm{min} / 1.73 \mathrm{~m}^{2}\right)^{\dagger}$ & $100.00 \pm 13.00$ & $97.00 \pm 18.00$ & 0.100 \\
\hline $\mathrm{WBC}\left(\times 10^{9} / \mathrm{L}\right)^{\dagger}$ & $11.05 \pm 3.17$ & $10.50 \pm 3.41$ & 0.836 \\
\hline Hemoglobin $(\mathrm{g} / \mathrm{dl})^{\dagger}$ & $14.30 \pm 2.00$ & $14.00 \pm 1.22$ & 0.435 \\
\hline $\mathrm{CRP}(\mathrm{mg} / \mathrm{L})^{\beta}$ & $4.41(1.37-112)$ & $4.40(1.0-95)$ & 0.992 \\
\hline Troponin $(\mathrm{ng} / \mathrm{L})^{\dagger}$ & $6.20 \pm 2.38$ & $8.82 \pm 2.35$ & 0.456 \\
\hline \multicolumn{4}{|l|}{ Medications at discharge } \\
\hline Aspirin & $201(98.5)$ & 124 (96.9) & 0.307 \\
\hline B-blocker ${ }^{*}$ & $192(94)$ & $124(96.9)$ & 0.254 \\
\hline Statins ${ }^{*}$ & $192(94)$ & $124(96.9)$ & 0.302 \\
\hline ACEIs or ARBs ${ }^{\star}$ & $200(98)$ & $124(96.9)$ & 0.491 \\
\hline Diuretics ${ }^{*}$ & $12(5.9)$ & $12(9.4)$ & 0.277 \\
\hline P2Y12 receptor inhibitors ${ }^{\ddagger}$ & $196(96)$ & $124(96.9)$ & 0.773 \\
\hline
\end{tabular}

${ }^{\dagger}:$ mean \pm standard deviation, ${ }^{\ddagger}: \mathrm{n}(\%),{ }^{\ddagger}$ : median (min-max).

SBP: Systolic Blood Pressure; LVEF: Left ventricular ejection fraction; ALT: Alanine aminotransferase; TC: Total cholesterol; LDL-C: Low-density lipoprotein cholesterol; HDLC: High-density lipoprotein cholesterol; eGFR: estimated glomerular filtration rate; WBC: White blood cell; CRP: C-reactive protein; ACEI: Angiotensin-converting enzyme inhibitor; ARB: Angiotensin II receptor blockers

Table 3 demonstrates the primary composite endpoints according to HbA1c category. The primary composite endpoints amounted to $7.4 \%$ and $15.6 \%$ in the nondiabetic and prediabetic group $(\mathrm{p}=0.026)$. The incidence of cardiovascular death and myocardial infarction were higher in the prediabetic than the nondiabetic ( $\mathrm{p}=0.021, \mathrm{p}=0.004$; respectively). The incidence of stroke was higher in the nondiabetic group $(\mathrm{p}=0.046)$ (Table 3$)$.

Table 1. Coronary artery disease, angiographic data and selection of revascularization among the study population.

\begin{tabular}{|c|c|c|c|}
\hline & $\begin{array}{c}\text { Non-diabetic patients } \\
(\mathrm{n}=204)\end{array}$ & $\begin{array}{l}\text { Prediabetic patients } \\
\qquad(\mathrm{n}=128)\end{array}$ & $\mathrm{p}$ \\
\hline \multicolumn{4}{|l|}{ Angiographic findings ${ }^{\ddagger}$} \\
\hline Left main & 0 & $8(6.3)$ & $<0.001$ \\
\hline Left anterior descending & $92(45)$ & $52(40)$ & 0.423 \\
\hline Left circumflex & $68(33)$ & $32(25)$ & 0.112 \\
\hline Right coronary artery & $72(35)$ & $56(43)$ & 0.123 \\
\hline TIMI thrombus grade & $4.0 \pm 3.0$ & $4.0 \pm 2.0$ & 0.171 \\
\hline SYNTAX Score & $6.0 \pm 5.0$ & $5.5 \pm 8.2$ & 0.968 \\
\hline \multicolumn{4}{|l|}{ Revascularization $^{\star}$} \\
\hline $\begin{array}{l}\text { Coronary artery bypass } \\
\text { grafting }\end{array}$ & $4(2)$ & $4(3.1)$ & 0.491 \\
\hline $\begin{array}{l}\text { Percutaneous coronary } \\
\text { intervention }\end{array}$ & $176(86.3)$ & $108(84.3)$ & 0.632 \\
\hline $\begin{array}{l}\text { Non-interventional } \\
\text { treatment }\end{array}$ & $24(11.7)$ & $16(12.6)$ & 0.464 \\
\hline
\end{tabular}

\%: $\mathrm{n}(\%)$

NSTEMI: Non-ST elevation myocardial infarction; STEMI: ST elevation myocardia infarction; TIMI: Thrombolysis in Myocardial Infarction; Syntax: SYNergy between PC with TAXUS and Cardiac Surgery.

Univariate logistic regression analyses showed that the SYNTAX score, TIMI grade, LVEF, STEMI, SBP, eGFR, hemoglobin and $\mathrm{HbA1c}$ (categorical variable) was significantly associated with the primary composite endpoints, as shown in Table 4. Independent predictors for the primary composite endpoints following the multivariate analysis included SYNTAX score, LVEF, SBP and HbA1c (categorical variable) (Table 4).

Table 3. Primary endpoints according to admission HbA1c.

\begin{tabular}{lccc} 
& $\begin{array}{c}\text { Non-diabetic } \\
\text { patients } \\
(\mathrm{n}=204)\end{array}$ & $\begin{array}{c}\text { Prediabetic } \\
\text { patients } \\
(\mathrm{n}=128)\end{array}$ & $\mathrm{p}$ \\
\hline Primary composite endpoints $^{\ddagger}$ & $15(7.4)$ & $20(15.6)$ & 0.026 \\
Cardiovascular death $^{\ddagger}$ & 0 & $4(3.1)$ & 0.021 \\
Myocardial infarction $^{\star}$ & $8(3.9)$ & $16(12.5)$ & 0.004 \\
Stroke $^{\ddagger}$ & $7(3.4)$ & 0 & 0.046 \\
\hline${ }^{\ddagger} \mathrm{n}(\%)$. & &
\end{tabular}

\section{Discussion}

The main findings were as follows: the prediabetes group has a higher incidence of primary compound endpoint than the nondiabetic group, despite similar medical history, angiographic findings, and revascularization selection. Incidence of cardiovascular death and myocardial infarction were higher in the prediabetic group. In addition, prediabetes status has been found predictive for the primary composite outcome. Contrary to expectations, the incidence of stroke was higher in the nondiabetic group.

It has been reported that $25-35 \%$ of patients who develop AMI are prediabetic [16, 17]. Ford et al. showed that the risk of CVD increased 0.65-2.5-fold in patients with fasting blood glucose of $110 \mathrm{mg} / \mathrm{dl}$ and above [18]. Satman et al. [19 ]reported that CVD risk increased 1.28-fold in patients with impaired fasting glucose $100-125 \mathrm{mg} / \mathrm{dL}$ and 1.20 -fold in those with $110-125 \mathrm{mg} / \mathrm{dL}$. It is known that the risk of developing CVD in prediabetic patients is significantly higher than those with normoglycemia [18]. In a study evaluating long-term follow-up results of the DECODE cohort, prediabetics with high OGTT (2nd hour) and high initial or fasting blood sugar values have reported an increased cardiovascular risk to the non-high group [20]. OGTT may cause misinterpretation in patients with AMI due to acute stress hormones during a peri-infarction period and may reflect incorrect plasma glucose levels [9]. 
Table 4. Univariate and multivariate logistic regression analyses for prediction of primary endpoints.

\begin{tabular}{|c|c|c|c|c|}
\hline & \multicolumn{2}{|l|}{ Univariate analysis } & Multivariate analysis & \multirow[b]{2}{*}{$\mathrm{p}$} \\
\hline & OR (95\% CI) & $\mathrm{p}$ & OR $(95 \%$ CI) & \\
\hline SYNTAX Score & $1.113(1.067-1.161)$ & $<0.001$ & $0.912(0.832-0.999)$ & 0.047 \\
\hline TIMI & $1.308(1.045-1.637)$ & 0.019 & $1.338(0.942-1.900)$ & 0.104 \\
\hline LVEF & $0.865(0.828-0.905)$ & $<0.001$ & $0.812(0.753-0.876)$ & $<0.001$ \\
\hline Age & $1.012(0.989-1.036)$ & 0.297 & & \\
\hline STEMI & $2.998(1.462-6.146)$ & 0.003 & $1.571(0.577-4.278)$ & 0.377 \\
\hline Heart Rate. & $1.008(0.984-1.031)$ & 0.532 & & \\
\hline SBP & $0.942(0.922-0.963)$ & $<0.001$ & $0.955(0.927-0.985)$ & 0.003 \\
\hline eGFR & $0.976(0.961-0.990)$ & 0.001 & $0.985(0.947-1.025)$ & 0.466 \\
\hline $\mathrm{Hb}$ & $0.719(0.613-0.843)$ & $<0.001$ & $0.867(0.590-1.275)$ & 0.469 \\
\hline $\mathrm{HbAlc}$ & $2.333(1.147-4.746)$ & 0.019 & $2.787(1.091-7.120)$ & 0.032 \\
\hline
\end{tabular}

OR: Odds ratio; $\mathrm{CI}$ : Confidence interval

Syntax: SYNergy between PCI with TAXUS and Cardiac Surgery; TIMI: Thrombolysis in Myocardial Infarction; LVEF: Left Ventricular Ejection Fraction; STEMI: ST elevation myocardial infarction; SBP: Systolic blood pressure; eGFR: estimated glomerular filtration rate; $\mathrm{Hb}$ : Hemoglobin.

In these previous studies, prediabetes status was evaluated with fasting blood glucose, impaired fasting glucose, or impaired glucose tolerance. In our study, prediabetes status was evaluated using HbA1c, considering the confounding effect of the catecholaminergic reaction in the AMI period. $\mathrm{HbA} 1 \mathrm{c}$ has recommended as a diagnostic test for prediabetes and DM in addition to conventional criteria based on fasting plasma glucose or the OGTT by the ADA [6]. Prediabetes status is considered to $\mathrm{HbA} 1 \mathrm{c}$ from 5.7 to $6.4 \%$ [20, 21]. The HbA1c has various benefits in the diagnosis of prediabetes in the status of AMI, for instance, fasting is not necessary, and as a marker of glycaemic control over the former $8-12$ weeks average, it is less affected than admission plasma glucose by acute stress reaction caused by AMI [22]. Elevated HbA1c has been shown to connect to cardiovascular mortality and be important for the prognosis after AMI in nondiabetics patients [23]. Tomizawa et al. [24] reported that patients with between $\mathrm{HbA} 1 \mathrm{c}$ levels $6.0-6.5 \%$ are potentially at risk of adverse cardiovascular events.

A significant proportion of dysglycemic patients develop vascular disorders during the prediabetes stage, although their glucometabolic impairment often remains undetected until the first cardiovascular event [25]. Free fatty acids, hyperglycemia, and insulin resistance in prediabetes status cause changes in blood vessels' function and structure [26]. Increased free fatty acid causes damage to the ischemic myocardium by increasing myocardial oxygen requirement, resulting in the occurrence of ventricular arrhythmias and depressed myocardial contractility [27]. The glucose dysregulation in prediabetes status has associated with the release of cytokines or cell death, inflammation, and consequent cardiomyopathy [28]. The vasoconstriction and inflammation increase and contribute to the progression of coronary atherosclerosis [29]. Prediabetes individuals have more advanced coronary artery disease such as diffuse coronary stenosis and impaired coronary collateral circulation compared to normoglycemia [16, 30]. Several mechanisms can explain the increased proportions of CVD in prediabetic individuals; the most widely accepted are all-day exposure of prediabetics to high blood sugar, high frequency of metabolic syndrome and vascular damage which is the cause of a diurnal cycle change and fluctuation of blood glucose levels in these patients [15, 31].

Previous studies reported that the mean age of the prediabetic acute coronary syndrome patients was higher than the nondiabetic acute coronary syndrome patients [32]. In this study, prediabetic patients were advanced age than nondiabetic patients. Although the risk of atherosclerotic coronary disease increases with age, nondiabetic patients who had AMI were younger age; it might be associated with the individual's other risk factors independent of high glucose levels.
It is known that prediabetes has a significant association with heart failure [33]. In our study, LVEF was found to be similar between groups, contrary to previous studies. The cardiovascular outcomes of prediabetes might be considered not yet reflected in the clinical findings. In addition, though the LVEF value was similar, the prediabetes group had higher cardiovascular mortality due to more AMI and complications rather than related heart failure.

In this study, the SYNTAX score showing coronary artery severity angiographically was similar between the groups, which were not surprising as no expected silent $\mathrm{MI}$ in prediabetes. Coronary atherosclerosis in diabetic patients is usually recognized at an advanced age, whereas the disease in its premature or asymptomatic stages regrettably frequently remains undetected or delayed [34]. Therefore, premature atherosclerosis in the prediabetic status might cause similar STYTAX and TIMI scores.

Several studies have evaluated the prevalence of prediabetes and DM type 2 in patients who had stroke and in the majority of those studies, the prevalence was assessed by OGTT and fasting plasma glucose [35]. Using impaired fasting glucose or impaired glucose tolerance level-based criteria, about $10 \%$ of the adult people were in prediabetes state, whereas $\mathrm{HbA1c}$-based criteria identify a significantly lower ratio of the patients [36]. Contrary to the literature, stroke was less frequent in prediabetic patients in this study. This situation has been considered associated with the small size of our study population and the diagnosis of prediabetes based on HbAlc.

First, this study was limited by the cross-sectional nature of patients presenting with AMI, a single-centre retrospective study, including a limited number of participants and results, may not be generalized to the population as a whole. Second, the effect of factors that can change HbA1c levels regardless of glycaemia, such as anaemia or hemoglobinopathies, should be considered. The development of cardiovascular diseases and the occurrence of diabetes complications are a long process. Therefore, the short follow-up time of our study may lead to lower cardiovascular disease incidence. It might not be consistent compliance with treatment regimens, which could be difficult to assess in retrospective data analysis. We did not perform the OGTT for diagnosing diabetes mellitus. Therefore, according to the criteria described in the Methods section, patients with undiagnosed diabetes might have been misclassified as nondiabetic.

In this study, the prediabetes group has been shown to have higher incidences of the cardiovascular death and myocardial infarction than nondiabetics. Our data have been consistent with previous studies showing that prediabetes was a risk factor for CVD [17]. Otten et al. demonstrated that impaired fasting glucose was an independent predictor of in-hospital outcome, including death, reinfarction and the composite of major cardiovascular adverse events in the different nondiabetic categories [38]. As a result of multivariate analysis, it was determined that HbA1c categorical variable and reduced LVEF, SBP and SYNTAX score were associated with the primary composite endpoints. In agreement with our study, the study by Naito et al. showed that reduced LVEF was an independent predictor of poor prognosis in nondiabetic patients with AMI [39]. It has also been reported that the SYNTAX score has been used in the estimation of long-term mortality and major adverse cardiovascular events in prediabetics [39]. Thus, preventive measures in the stage of prediabetes might help the prevention of developing CVD. 


\section{References}

1. Authors/Task Force Members, Rydén L, Grant PJ, Anker SD, Berne C, Cosentino F, Danchin N, et al. ESC Guidelines on diabetes, pre-diabetes, and cardiovascular diseases developed in collaboration with the EASD: the Task Force on diabetes, prediabetes, and cardiovascular diseases of the European Society of Cardiology (ESC) and developed in collaboration with the European Association for the Study of Diabetes (EASD). Eur Heart J. 2013;34:3035-87.

2. Deedwania P, Kosiborod M, Barrett E, Ceriello A, Isley W, Mazzone T, et al. Hyperglycemia and acute coronary syndrome: a scientific statement from the American Heart Association Diabetes Committee of the Council on Nutrition, Physical Activity, and Metabolism. Anesthesiology. 2008;109:14-24

3. Yusuf S, Hawken S, Ounpuu S, Dans T, Avezum A, Lanas F, et al. Effect of potentially modifiable risk factors associated with myocardial infarction in 52 countries (the INTERHEART study): case-control study. Lancet. 2004; 364: 937-52.

4. Balkau B. The DECODE study. Diabetes epidemiology: collaborative analysis of diagnostic criteria in Europe. Diabetes Metab. 2000;26:282-6.

5. Rao Kondapally Seshasai S, Kaptoge S, Thompson A, Thompson A, Di Angelantonio E, Gao P, et al. Diabetes mellitus, fasting glucose, and risk of cause-specific death. N Engl J Med. 2011;364:829-41.

6. American Diabetes Association. 2. Classification and Diagnosis of Diabetes: Standards of Medical Care in Diabetes-2018. Diabetes Care. 2018;41:S14-s31.

7. Ceyhan K, Altunkaş F. Prediabetes, becoming the equivalent of coronary artery disease. Turk Kardiyol Dern Ars. 2012;40:45865 .

8. Gillett MJ. International Expert Committee report on the role of the A1c assay in the diagnosis of diabetes: Diabetes Care 2009;32:1327-13. Clin Biochem Rev. 2009;30:197-200.

9. Lankisch M, Füth R, Gülker H, Lapp H, Bufe A, Haastert B, et al. Screening for undiagnosed diabetes in patients with acute myocardial infarction. Clin Res Cardiol. 2008;97:753-9.

10. Vistisen D, Witte DR, Brunner EJ, Kivimäki M, Tabák A, Jørgensen ME, et al. Risk of Cardiovascular Disease and Death in Individuals With Prediabetes Defined by Different Criteria: The Whitehall II Study. Diabetes Care. 2018;41:899-906.

11. Huang Y, Cai X, Mai W, Li M, Hu Y. Association between prediabetes and risk of cardiovascular disease and all cause mortality: systematic review and meta-analysis. BMJ. 2016;355:i5953.

12. Warren B, Pankow JS, Matsushita K, Punjabi NM, Daya NR, Grams M, et al. Comparative prognostic performance of definitions of prediabetes: a prospective cohort analysis of the Atherosclerosis Risk in Communities (ARIC) study. Lancet Diabetes Endocrinol. 2017;5:34-42.

13. Thygesen K, Alpert JS, Jaffe AS, Chaitman BR, Bax JJ, Morrow DA, et al. Fourth Universal Definition of Myocardial Infarction (2018). J Am Coll Cardiol. 2018; 72: 2231-64.

14. Diagnosis and classification of diabetes mellitus. Diabetes Care. 2010;33:S62-9.

15. American Diabetes Association. Standards of medical care in diabetes--2013. Diabetes Care. 2013;36:S11-66.

16. Norhammar A, Tenerz A, Nilsson G, Hamsten A, Efendíc S, Rydén L, et al. Glucose metabolism in patients with acute myocardial infarction and no previous diagnosis of diabetes mellitus: a prospective study. Lancet. 2002;359:2140-4.

17. Kataoka Y, Yasuda S, Morii I, Otsuka Y, Kawamura A, Miyazaki S. Quantitative coronary angiographic studies of patients with angina pectoris and impaired glucose tolerance. Diabetes Care. 2005;28:2217-22

18. Ford ES, Zhao G, Li C. Pre-diabetes and the risk for cardiovascular disease: a systematic review of the evidence. J Am Coll Cardiol. 2010;55:1310-7.

19. Satman I, Yilmaz T, Sengül A, Salman S, Salman F, Uygur S, et al. Population-based study of diabetes and risk characteristics in Turkey: results of the turkish diabetes epidemiology study (TURDEP). Diabetes Care. 2002;25:1551-6.

20. Ning F, Tuomilehto J, Pyörälä K, Onat A, Söderberg S, Qiao Q; DECODE Study Group. Cardiovascular disease mortality in Europeans in relation to fasting and 2-h plasma glucose levels within a normoglycemic range. Diabetes Care. 2010;33:2211-6.
21. Chatterton H, Younger T, Fischer A, hunti K; Programme Development Group. Risk identification and interventions to prevent type 2 diabetes in adults at high risk: summary of NICE guidance. BMJ. 2012;345:e4624.

22. Timmer JR, Van Der Horst IC, Ottervanger JP, Henriques JP, Hoorntje JC, de Boer MJ, et al. Prognostic value of admission glucose in non-diabetic patients with myocardial infarction. Am Heart J. 2004;148:399-404.

23. Chowdhury TA, Lasker SS. Elevated glycated haemoglobin in non-diabetic patients is associated with an increased mortality in myocardial infarction. Postgrad Med J. 1998;74:480-1.

24. Tomizawa N, Inoh S, Nojo T, Nakamura S. The association of hemoglobin A1c and high risk plaque and plaque extent assessed by coronary computed tomography angiography. Int $\mathrm{J}$ Cardiovasc Imaging. 2016;32:493-500.

25. Anselmino M, Wallander M, Norhammar A, Mellbin L, Rydén L. Implications of abnormal glucose metabolism in patients with coronary artery disease. Diab Vasc Dis Res. 2008;5:285-90.

26. Brownlee M. Advanced protein glycosylation in diabetes and aging. Annu Rev Med. 1995;46:223-34.

27. Oliver MF. Sudden cardiac death: the lost fatty acid hypothesis. QJM. 2006;99:701-9.

28. Lal N, Chiu AP, Wang F, Zhang D, Jia J, Wan A, et al. Loss of VEGFB and its signaling in the diabetic heart is associated with increased cell death signaling. Am J Physiol Heart Circ Physiol. 2017;312:H1163-75.

29. Grundy SM. Pre-diabetes, metabolic syndrome, and cardiovascular risk. J Am Coll Cardiol. 2012;59:635-43.

30. Kadi H, Ceyhan K, Karayakali M, Celik A, Ozturk A, Koc F, et al. Effects of prediabetes on coronary collateral circulation in patients with coronary artery disease. Coron Artery Dis. 2011;22:233-7.

31. Goldberg RB, Temprosa M, Haffner S, Orchard TJ, Ratner RE, Fowler SE, et al. Effect of progression from impaired glucose tolerance to diabetes on cardiovascular risk factors and its amelioration by lifestyle and metformin intervention: the Diabetes Prevention Program randomized trial by the Diabetes Prevention Program Research Group. Diabetes Care. 2009;32:726-32.

32. Barr EL, Zimmet PZ, Welborn TA, Jolley D, Magliano DJ, Dunstan DW, et al. Risk of cardiovascular and all-cause mortality in individuals with diabetes mellitus, impaired fasting glucose, and impaired glucose tolerance: the Australian Diabetes, Obesity, and Lifestyle Study (AusDiab). Circulation. 2007;116:151-7.

33. Kristensen SL, Preiss D, Jhund PS, Squire I, Cardoso JS, Merkely B, et al. Risk Related to Pre-Diabetes Mellitus and Diabetes Mellitus in Heart Failure With Reduced Ejection Fraction: Insights From Prospective Comparison of ARNI With ACEI to Determine Impact on Global Mortality and Morbidity in Heart Failure Trial. Circ Heart Fail. 2016; 9:e002560.

34. Scognamiglio R, Negut C, Ramondo A, Tiengo A, Avogaro A. Detection of coronary artery disease in asymptomatic patients with type 2 diabetes mellitus. J Am Coll Cardiol. 2006;47:65-71.

35. Fonville S, Zandbergen AA, Koudstaal PJ, den Hertog HM. Prediabetes in patients with stroke or transient ischemic attack: prevalence, risk and clinical management. Cerebrovasc Dis. 2014;37:393-400.

36. Bansal N. Prediabetes diagnosis and treatment: A review. World J Diabetes. 2015;6:296-303.

37. Otten R, Kline-Rogers E, Meier DJ, Dumasia R, Fang J, May $\mathrm{N}$, et al. Impact of pre-diabetic state on clinical outcomes in patients with acute coronary syndrome. Heart. 2005;91:1466-8.

38. Naito R, Miyauchi K, Ogita M, Kasai T, Kawaguchi Y, Tsuboi $\mathrm{S}$, et al. Impact of admission glycemia and glycosylated hemoglobin A1c on long-term clinical outcomes of non-diabetic patients with acute coronary syndrome. J Cardiol. 2014;63:10611.

39. Magro M, Nauta S, Simsek C, Onuma Y, Garg S, van der Heide E, et al. Value of the SYNTAX score in patients treated by primary percutaneous coronary intervention for acute STelevation myocardial infarction: The MI SYNTAXscore study. Am Heart J. 2011;161:771-81. 